Jurnal Penelitian dan Pengabdian Kepada Masyarakat Bidang ilmu Pendidikan

\title{
Pengembangan Perangkat Pembelajaran Penanganan dan Perawatan Cidera (PPC) "Lo,i Ncara ro Mpoka" menggunakan Hellison's Model terhadap Berpikir Kreativitas Mahasiswa
}

\author{
Amal Fauqi ${ }^{1}$, Arif Bulan ${ }^{2}$ \\ ${ }^{1}$ Dosen Program Studi Pendidikan Jasmani kesehatan dan Rekreasi, STKIP Yapis Dompu \\ 2 Dosen Program Studi Pendidikan Bahasa Inggris, STKIP Yapis Dompu \\ E-mail: amalfauqi@gmail.com, arifbulan1@gmail.com
}

Article History: Received: 2022-01-11 || Revised: 2022-02-01 || Published: 2022-02-08

Sejarah Artikel : Diterima: 2022-01-11 || Direvisi: 2022-02-01 || Dipublikasi: 2022-02-08

\begin{abstract}
Development of Learning Devices Using Hellison's Model aims to give students the freedom to be responsible, independent and take creative, scientific steps by collecting data from learning outcomes, then students can interpret, analyze, and finally come to a conclusion, so it is hoped that Student learning achievement grows and increases. This research is a developmental research, by developing learning tools that include: textbooks, lesson plans, worksheets and instruments for students' creative thinking skills that refer to the 4-D model (Define, Design, Develop, and Deisemination). Based on the results of descriptive analysis, the development of Hellison's Model Learning Tools in the Injury Handling and Treatment Course "Loi Ncara Ro Mpoka" to Train Students' Creative Thinking Ability is categorized as Eligible or "Very Good", because the six criteria for good learning tools are met. Overall this Learning Toolkit for handling and treating sports injuries is appropriate to be used in the implementation of Handling and treating sports injuries for students after going through 2 trial stages. This development research has been achieved for use by teachers in introducing the handling and treatment of sports injuries to students.
\end{abstract}

Keywords: Learning, PPC, Hellison's Model, Creative Thinking.

\begin{abstract}
Abstrak
Pengembangan Perangkat Pembelajaran dengan Menggunakan Hellison's Model bertujuan untuk memberikan kebebasan pada Mahasiswa untuk bertanggung Jawab, Mandiri serta melakukan langkah-langkah kreatif, ilmiah dengan cara mengumpulkan data dari hasil pembelajaran, kemudian Mahasiswa dapat menafsirkan, menganalisis, dan akhirnya sampai pada suatu kesimpulan, sehingga diharapkan prestasi belajar Mahasiswa menjadi tumbuh dan meningkat. Penelitian ini merupakan penelitian pengembangan (developmental research), dengan mengembangkan perangkat pembelajaran yang meliputi: Buku Ajar, RPS, Worksheet serta instrument kemampuan berpikir kreatif Mahasiswa yang mengacu pada model 4-D (Define, Design, Develop, dan Deisemination). Berdasarkan hasil analisis deskriptif, pengembangan Perangkat Pembelajaran Hellison's Model pada Mata Kuliah Penanganan dan Perawatan Cedera "Loi Ncara Ro Mpoka" untuk Melatih Kemampuan Berpikir Kreatif Mahasiswa diketegorikan Layak atau "Sangat Baik", karena keenam kriteria perangkat pembelajaran yang baik terpenuhi. Secara keseluruhan Perangkat Pembelajaran Penanganan dan perawatan cedera olahraga ini layak digunakan dalam penerapan Penanganan dan perawatan cedera olahraga untuk Mahasiswa setelah melalui 2 tahap uji coba. Penelitian pengembangan ini sudah tercapai untuk digunakan oleh Dosen dalam memperkenalkan Penanganan dan perawatan cedera olahraga kepada mahasiswa.
\end{abstract}

Kata kunci: Pembelajaran, PPC, Hellison's Model, Berpikir Kreatif.

\section{PENDAHULUAN}

Penerapan pembelajaran di pendidikan tinggi harus menggunakan pendekatan-pendekatan pembelajaran inovatif dalam mentranspormasikan ilmu pengetahuan, baik yang menyangkut teori maupun praktek. Tujuanya adalah agar pembelajaran bermakna dan arah agar prinsip pembelajaran kontekstual dan berpusat pada Mahasiswa dapat terjadi. Ini berarti proses pembelajaran di pendidikan tinggi juga harus mengakomodasi adanya Mahasiswa dalam kelompok heterogen. dalam hal ini perlu mendapat perlakuan sedemikian rupa sehingga potensi masing- 
masing pribadi tersebut dapat berkembang secara optimal. Secara akademik dan empirik, tidak ada satupun model proses pembelajaran yang sesuai untuk setiap mata kuliah dengan bidang keilmuan dengan Mahasiswa yang beragam. Untuk itu dosen harus mampu memilih, mengembangkan, dan menerapkan model pembelajaran yang sesuai dengan karakteristik mata kuliah, karakteristik Mahasiswa, serta kondisi dan situasi lingkungan. Hal ini menunjukkan posisi penting proses pembelajaran dalam menghasilkan lulusan yang bermutu. Pada lingkup yang lebih kecil dalam proses pembelajaran (perkuliahan) sebagai konsekuensi logis implementasi suatu kurikulum, maka dalam interaksi proses pembelajaran tersebut harus disiapkan perangkat pembelajaran secara baik. Penyiapan perangkat pembelajaran yang baik merupakan langkah strategis dalam pengelolaan proses pembelajaran untuk mencapai capaian pembelajaran yang maksimal.

Perangkat pembelajaran yang digunakan pada mata kuliah Penanganan dan Perawatan Cedera (PPC) prodi Penjaskesrek STKIP Yapis Dompu kurang inovatif atau masih bersifat statis misalnya Mahasiswa diberikan pengetahuan, apabila seorang atlet mengalami cedera, solusinya langsung dibawa ke rumah sakit ataupun dokter spesialis cedera. Selama ini Mahasiswa tidak diajarkan pengetahuan tentang adanya alternatif solusi lain dalam mengahadapi permasalahan cedera selain daripada rumah sakit ataupun dokter spesialis cedera. Alternatif solusi lain yang dimaksud ialah dengan memanfaatkan tumbuhan lokal sebagai sumber obat-obatan yang dapat dikembangkan sebagai alternatif pilihan untuk mengobati berbagai jenis penyakit termasuk didalamnya berkaitan dengan cedera fisik, selain itu efek negatif yang ditimbulkan dari penggunaan obat tradisional lebih kecil jika dibandingkan dengan penggunaan obatan berbahan kimia (modern). Melihat persoalan di atas, seorang dosen perlu kiranya untuk mengembangkan sebuah perangkat pembelajaran dalam penanganan dan perawatan cedera (PPC) yang kreatif dan inovatif dengan mengintegrasaikan budaya daerah untuk menjawab kebutuhan dan pengetahuan Mahasiswa, khusunya dalam hal ini Mahasiswa Program Studi Pendidikan Jasmani Kesehatan dan Rekreasi.

Pengintegrasian budaya daerah didalam perangkat pembelajaran merupakan salah satu bentuk upaya dalam menjaga serta melestarikan budaya daerah. Sejalan dengan hal tersebut, perlindungan budaya daerah telah diatur dalam Revisi Undang-undang (RUU) Nomer 5 Tahun 2017 yang menyatakan bahwa "Kebudayaan telah menjadi akar dari pendidikan kita, oleh karena itu, RUU Pemajuan Kebudayaan perlu menekankan pada pelindungan, pengembangan, pemanfaatan, dan pembinaan agar budaya Indonesia dapat tumbuh tangguh". (Taufik (2020) Salah satu daerah yang masih mempertahankan tradisi budayanya, yakni daerah Bima dan Dompu, dimana daerah Bima dan Dompu merupakan wilayah hot spot biodiversitas termasuk kekayaan ragam tumbuhan obat dan sebagai daerah yang masyarakatnya masih mempertahankan tradisi dalam menangani segala bentuk penyakit dengan obat tradisional yang di maksud Peneliti adalah pengobatan perawatan Cedera Keseleo dan patah tulang (fraktur) "Lo'i Ncara ro Mpoka" dengan memanfaatkan keahlian sumber daya Manusia, yakni tukang pijit (sando).

Berdasarkan uraian di atas, peneliti tertarik untuk mengembangkan "Perangkat Pembelajaran Penanganan dan Perawatan Cidera (PPC) "Lo'i Ncara ro Mpoka” Menggunakan Hellison's Model Terhadap Kemampuan berpikir Kreativitas Mahasiswa Program Studi Pendidikan Jasmani Kesehatan dan Rekreasi.

\section{METODE PENELITIAN}

Penelitian ini merupakan penelitian pengembangan atau Research dan Development (R\&D). Menurut Sugiyono (2009:297), metode penelitian pengembangan yaitu metode penelitian yang digunakan untuk menghasilkan Perangkat Pembelajaran tertentu dan menguji kelayakan Perangkat Pembelajaran tersebut. Borg dan Gall (1983: 772) mengemukakan penelitian pengembangan (R\&D) adalah proses yang digunakan untuk mengembangkan dan mengvalidasi Perangkat Pembelajaran Kenyataannya, tujuan dari penelitian pendidikan bukanlah hanya saja untuk 
mengembangkan Perangkat Pembelajaran, namun agak mengarah pada penemuan pengetahuan baru (melalui penelitian dasar). Dengan mengembangkan perangkat pembelajaran yang meliputi: RPS, LKM, Buku Ajar serta instrument kemampuan berpikir kreatif mahasiswa yang mengacu pada model 4-D (Four-D) Model. Penelitian ini dilaksanakan di Mahasiswa STKIP Yapis Dompu pada Program Studi Pendidikan Jasmani, kesehatan dan Rekreasi Semester V dengan jumlah 30 Orang Mahasiswa, tahun pembelajaran 2021/2022, Adapun Prosedur yang digunakan dalam penelitian pengembangan ini mengadopsi dari model menurut Sugiyono (2009:298). Berikut ini adalah diagram alur jalannya dan langkah-langkah dalam penelitian ini:

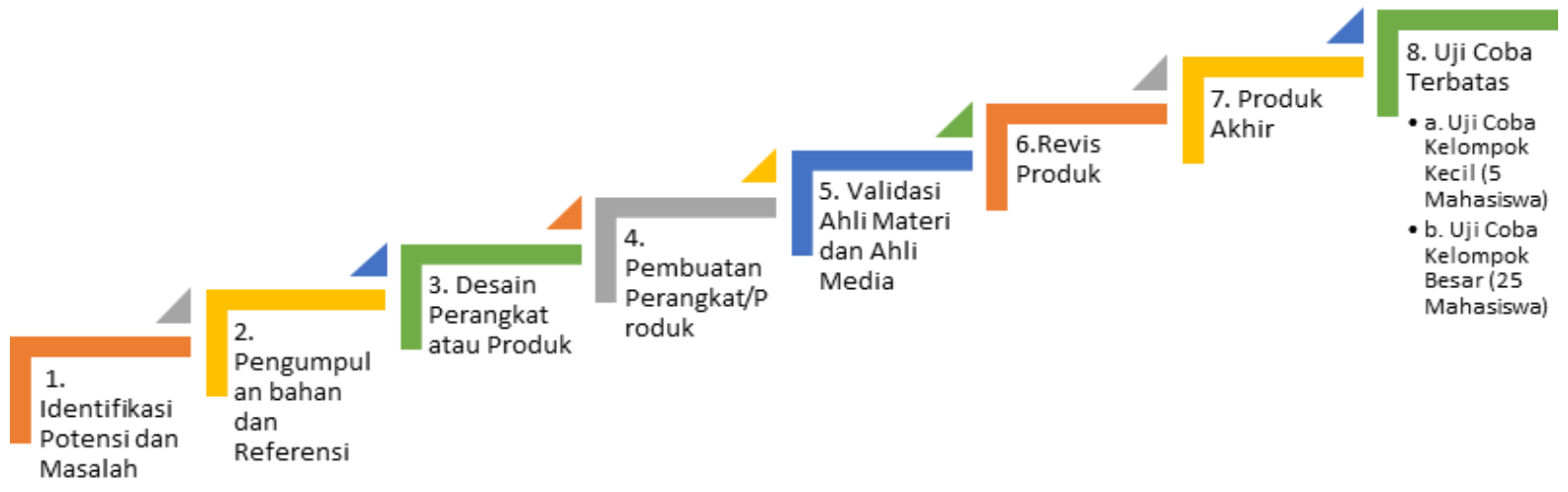

Gambar 1. Model Pengembangan Perangkat Pembelajaran PPC

1. Penanganan dan Perawatan Cedera Olahraga

Subyek uji coba dalam penelitian pengembangan ini adalah Mahasiswa . Uji coba tersebut dilakukan melalui beberapa tahapan. Tahap pertama adalah uji coba kelompok dengan jumlah subyek penelitian sebanyak 5 Mahasiswa, tahap kedua adalah uji coba kelompok besar dengan jumlah subyek penelitian sebanyak 25 Mahasiswa. Instrumen dalam penelitian pengembangan ini adalah dengan menggunakan angket, teknik analisis data yang digunakan dalam penelitian ini diantaranya analisis kuantitatif deskriptif persentase. Data dari analisis isi tersebut bersifat kualitatif yang diperoleh melalui kegiatan validasi ahli dan kegiatan uji coba, yang berupa masukan, tanggapan, serta, kritik dan saran. Data yang bersifat kuantitatif yang berupa penilaian, yang dihimpun melalui angket uji coba Perangkat Pembelajaran, pada saat kegiatan uji coba, dianalisis dengan analisis kuantitatif deskriptif. Angket yang digunakan dalam penelitian ini adalah angket penilaian atau tanggapan dengan bentuk jawaban "SANGAT KURANG”, "KURANG”, “CUKUP”, "BAIK”, dan "SANGAT BAIK”. Berdasarkan jumlah pendapat atau jawaban tersebut, kemudian peneliti mempersentasekan masing-masing jawaban menggunakan rumus Sugiyono (201:559), dta yang didapatkan kemudian dihitung, kemudian presentase yang didapatkan dikonversikan ke dalam tabel konversi yang dipaparkan oleh Sugiyono (2013:93) berikut:

Tabel 1. Konversi Penilaian Berdasarkan Persentase

\begin{tabular}{cccl}
\hline No & Presentase & Nilai & Kategori \\
\hline 1 & $81 \%-100 \%$ & A & Sangat Baik \\
\hline 2 & $61 \%-80 \%$ & B & Baik \\
\hline 3 & $41 \%-60 \%$ & C & Cukup Baik \\
\hline 4 & $40 \%-21 \%$ & D & Kurang \\
\hline 5 & $0 \%-20 \%$ & E & Sangat Kurang \\
\hline
\end{tabular}


2. Instrumen Penelitian

Instrument penelitian yang digunakan dalam penelitian ini yaitu::

a. Lembar Validasi Perangkat Pembelajaran

Lembar validasi perangkat pembelajaran terdiri dari lembar validasi RPS, lembar validasi Work Sheet, lembar validasi Tes Kemampuan Berpikir Kreatif, lembar validasi Buku Ajar.

b. Sheet Work

Sheet Work digunakan untuk memperoleh informasi berkaitan dengan kegiatan belajar mahasiswa selama uji coba.

c. Lembar observasi kemampuan dosen mengelola pembelajaran

Instrumen ini digunakan untuk mengamati beberapa aspek kemampuan dosen, yang berkaitan dengan tahapan model Hellison's

d. Angket respon mahasiswa

Respon mahasiswa adalah tanggapan mahasiswa setelah diterapkan perangkat pembelajaran menggunakan model Hollison's untuk meningkatkan kreativitas mahasiswa.

e. Tes Hasil Belajar

Tes Hasil Belajar digunakan untuk memperoleh informasi tentang hasil belajar secara klasikal. Bentuk tes adalah uraian dan penilaian bergantung pada kesulitan soal. Agar tes yang disusun berkualitas memadai, maka diperlukan analisis butir. Analisis butir tes meliputi uji validitas, uji reliabilitas, dan uji sensitivitas.

\section{Teknik Analisis Data}

a. Analisis Data Validasi

Data hasil penilaian para ahli untuk tiap-tiap perangkat pembelajaran dianalisis dengan mempertimbangkan masukan, komentar, dan saran-saran dari validator. Hasil analisis tersebut dijadikan sebagai pedoman untuk merevisi perangkat pembelajaran. Data hasil penilaian dari validator dianalisis berdasarkan pada rata-rata skor:

$00 \leq$ Rata-rata $\leq 20$ Sangat Kurang

$21<$ Rata-rata $\leq 40$ Kurang

$41<$ Rata-rata $\leq 60$ Cukup Baik

$61<$ Rata-rata $\leq 80$ Baik

$81<$ Rata-rata $\leq 100$ Sangat Baik

Perangkat pembelajaran dikatakan valid jika untuk setiap perangkat pembelajaran berada pada kategori rata-rata lebih dari 25 Dengan demikian, hasil analisis data yang tidak memenuhi salah satu kategori baik atau sangat baik maka akan dijadikan bahan pertimbangan untuk merevisi perangkat pembelajaran.

b. Analisis Data Uji Coba

1) Analisis data kemampuan dosen mengelola pembelajaran

Data tentang kemampuan dosen mengelola pembelajaran dianalisis dengan menggunakan statistik deskriptif yaitu dengan skor rata-rata. Adapun pendeskripsian skor rata-rata tingkat kemampuan dosen adalah sebagai berikut:

$00 \leq$ Rata-rata $\leq 20$ Sangat Kurang

$21<$ Rata-rata $\leq 40$ Kurang

$41<$ Rata-rata $\leq 60$ Cukup Baik

$61<$ Rata-rata $\leq 80$ Baik

$81<$ Rata-rata $\leq 100$ Sangat Baik

Kemampuan dosen mengelola pembelajaran dikatakan efektif jika rata-rata skor dari setiap aspek yang dinilai untuk setiap RPS berada pada kategori minimal baik. Dengan demikian maka hasil analisis data yang tidak memenuhi dari salah satu kategori baik atau 
sangat baik, akan dijadikan bahan pertimbangan untuk merevisi perangkat pembelajaran yang telah diujicoba.

2) Analisis data aktivitas mahasiswa

Data hasil pengamatan aktivitas mahasiswa dalam pembelajaran dianalisis dengan persentase. Persentase pengamatan aktivitas mahasiswa yaitu frekuensi setiap aspek pengamatan dibagi dengan total frekuensi semua aspek pengamatan dikalikan 100\%.Penentuan kesesuaian aktivitas mahasiswa berdasarkan pada alokasi waktu dalam rencana pembelajaran (selanjutnya disebut waktu ideal) dengan toleransi 10\% diambil berdasarkan taraf kesalahan dalam pengambilan keputusan yang diperbolehkan untuk penelitian-penelitian sosial dan pendidikan, aktivitas mahasiswa dikatakan efektif apabila waktu yang digunakan untuk melakukan setiap aspek aktivitas sesuai dengan alokasi waktu yang termuat setiap RPP dengan toleransi 10\% dengan demikian, aspek-aspek aktivitas Mahasiswa yang tidak memenuhi kriteria waktu ideal dengan toleransi 10\% akan dijadikan dasar untuk merevisi perangkat pembelajaran.

3) Data Respon Mahasiswa

Data tentang respon Mahasiswa diperoleh melalui angket yang dianalisis dengan menggunakan statistik deskriptif dengan persentase. Persentase dari setiap respon mahasiswa dihitung dengan rumus:

\section{$\frac{\text { Iumlah respon positif untuk setiap aspek }}{\text { Jumlah seluruh siswa }} \times 100 \%$}

Respon mahasiswa dikategorikan positif jika mahasiswa memilih pernyataan "setuju/senang", atau "sangat setuju/sangat senang" untuk aspek positif, dan memilih pernyataan "tidak setuju/tidak senang" atau "sangat tidak setuju/sangat tidak senang" untuk aspek negatif yang tertera pada angket dengan persentase $\geq 90 \%$. Untuk aspekaspek yang persentasenya kurang dari 91\% maka akan digunakan sebagai dasar untuk merevisi perangkat pembelajaran.

c. Analisis data tes hasil belajar.

Analisis data tes hasil belajar secara deskriptif bertujuan untuk mendeskripsikan hasil tes hasil belajar Hasil Belajar. Data yang dianalisis adalah data postes. Seorang Mahasiswa dikatakan tuntas belajarnya secara individual jika skor yang diperoleh Mahasiswa tersebut lebih dari atau sama dengan $70 \%$ dari skor total. Sedangkan ketuntasan belajar secara klasikal tercapai bila pada kelas tersebut lebih dari atau sama dengan $85 \%$ mahasiswa tuntas belajarnya.

\section{HASIL DAN PEMBAHASAN}

\section{A. Hasil Penelian}

Pengembangan Perangkat Pembelajaran Penanganan dan perawatan cedera olahraga ini divalidasi oleh para ahli dibidangnya, yaitu seorang ahli media pembelajaran dan ahli materi kesehatan. Adapun hasil penilaian terhadap Perangkat Pembelajaran yang disusun adalah sebagai berikut:

Tabel 2. Data Hasil Penilaian Perangkat Pembelajaran oleh Ahli Pakar Satu

\begin{tabular}{c|c|c|c|c|c}
\hline \multicolumn{7}{c}{ Vadidasi Materi Tahap Kedua } \\
\hline No & Aspek Yang di Nilai & $\begin{array}{c}\text { Skor yang } \\
\text { Diperoleh }\end{array}$ & $\begin{array}{c}\text { Skor } \\
\text { Maksimal }\end{array}$ & Presentase (\%) & Kategori \\
\hline 1 & Kelayakan Isi Materi & 64 & 68 & 96 & Sangat Baik \\
\hline \multicolumn{2}{r|}{ Skor Total } & 64 & 68 & 96 & Sangat Baik
\end{tabular}


Pada validasi tahap kedua persentase yang didapatkan mengalami peningkatan dari $70 \%$ menjadi 90\% dari skor maksimal. Dengan demikian dapat dinyatakan bahwa menurut ahli media, pada tahap validasi kedua Perangkat Pembelajaran yang dikembangkan dari aspek kelayakan isi materi mendapatkan kategori "sangat baik". Pada validasi kedua, ahli media memberikan komentar bahwa buku sudah bagus sekali dan menyarankan agar penjilidan buku lebih rapi.

Tabel 3. Data Hasil Penilaian Perangkat Pembelajaran oleh Ahli Pakar Media Tahap Kedua

\begin{tabular}{c|c|c|c|c|c}
\hline \multicolumn{9}{c}{ Vadidasi Materi Tahap Kedua } \\
\hline \multirow{2}{*}{ No } & Aspek Yang di Nilai & $\begin{array}{c}\text { Skor yang } \\
\text { Diperoleh }\end{array}$ & $\begin{array}{c}\text { Skor } \\
\text { Maksimal }\end{array}$ & Presentase (\%) & Kategori \\
\hline 1 & Kelayakan Isi Mater & 60 & 65 & 90 & Sangat Baik \\
\hline \multicolumn{2}{r|}{ Skor Total } & 60 & 65 & 90 & Sangat Baik
\end{tabular}

Uji coba lapangan dilakukan pada tanggal 4 Januari 2022 kepada 30 Mahasiswa STKIP Yapis Dompu Prodi Penjaskesrek Semester V.

Tabel 4. Hasil Angket Uji Coba Kelompok Besar

\begin{tabular}{c|l|c|c|c|c}
\hline \multicolumn{5}{c}{ Vadidasi Materi Tahap Kedua } \\
\hline No & \multicolumn{1}{|c|}{ Aspek Yang di Nilai } & $\begin{array}{c}\text { Skor yang } \\
\text { Diperoleh }\end{array}$ & $\begin{array}{c}\text { Skor } \\
\text { Maksimal }\end{array}$ & $\begin{array}{c}\text { Presentas } \\
\text { e (\%) }\end{array}$ & Kategori \\
\hline 1 & Isi Materi & 360 & 380 & 88 & Sangat Baik \\
\hline 2 & Kertebacaan Bahasa & 685 & 750 & 90 & Sangat Baik \\
\hline 3 & $\begin{array}{l}\text { Penyajian Perangkat Pembelajaran } \\
\text { Buku Ajar, LKM, RPS, Instrumen tes } \\
\text { Berpikir Kreatif Mahasiswa) }\end{array}$ & 365 & 380 & 92 & Sangat Baik \\
\hline 4 & $\begin{array}{l}\text { Komposisi Perangkat unangat Baik } \\
\text { Pembelajaran/Ramuan “Loi Ncara Ro } \\
\text { Mpoka Skor Total }\end{array}$ & 570 & 650 & 90 & Sangat Baik \\
\hline
\end{tabular}

Berdasar pada masukan dan saran dari ahli dan hasil uji coba skala besar di Mahasiswa, maka dapat dirumuskan Perangkat Pembelajaran akhir dari penelitian ini. Berdasarkan data yang diperoleh dalam penelitian ini, analisis data dilakukan secara cermat dan teliti dengan analisis data yang diperoleh ini menghasilkan beberapa hal sebagai berikut:

1) Berdasarkan catatan dari ahli media dan ahli materi, maka diputuskan untuk melakukan revisi yaitu pada materi agar menambah mengenai materi patah tulang, dan ahli media agar memperbaiki desain serta gambar pada buku agar lebih menarik, Ketajaman Soal kemampuan Berpikir Kreatif harus Memenuhi Indikatornya dan serta pemenuhan Capain Mata kulaih harus terarah.

2) Setelah dilakukan revisi maka dilakukan uji coba kelompok kecil dengan 5 Mahasiswa.

3) Setelah melakukan uji coba kelompok kecil maka dilanjutkan dengan uji coba kelompok besar dengan 25 Mahasiswa.

4) Berdasarkan tes uji coba kelompok kecil dan kelompok besar maka menunjukkan hasil tes dalam kategori sangat baik atau perangkat pembelajaran ini layak untuk di Pakai untuk Meningkatkan Kemampuan Berpikir Kreatif Mahasiswa.

Hasil data yang diperoleh diinterpretasikan menurut kategori yang telah ditentukan. Kategori yang digunakan dalam penelitian pengembangan ini dibagi menjadi beberapa bagian, yaitu untuk nilai 0-20\% dikategorikan tidak sangat kurang, 21-40\% dikategorikan kurang, 41-60\% dikategorikan cukup, 61-80\% dikategorikan baik, dan 81-100\% dikategorikan sangat baik.

\section{B. Pembahasan}

Pengembangan Perangkat Pembelajaran ini didesain menjadi sebuah Perangkat Pembelajaran awal berupa Perangkat Pembelajaran untuk memperkenalkan Penanganan dan 
perawatan cedera olahraga untuk Mahasiswa. Proses pengembangan melalui prosedur penelitian dan pengembangan, beberapa perencanan. Perangkat Pembelajaran dikembangkan dengan bertujuan untuk meningkatkan kemapuan berpikir Kreatif mahasiswa bagaimana mahasiswa bersikap, mandiri, tanggung jawab dan memiliki kepekaan terhadap sesama, setelah Perangkat Pembelajaran awal dihasilkan maka perlu dievaluasi kepada para ahli melalui validasi dan perlu diuji cobakan kepada Mahasiswa. Pada Tahap Tahap evaluasi dilakukan pada ahli materi dan ahli media. Sedangkan tahap penelitian dilakukan dengan uji coba kelompok kecil dan uji coba kelompok besar.

Proses validasi ahli materi menghasilkan data yang dapat digunakan untuk revisi Perangkat Pembelajaran awal. Proses validasi ahli materi ini peneliti menggunakan dua tahap yaitu tahap I dan tahap II. Data validasi tahap I dijadikan dasar untuk merevisi Perangkat Pembelajaran yang kedua. Setelah selesai revisi yang kedua divalidasi lagi hingga Perangkat Pembelajaran siap digunakan untuk uji coba. Setelah selesai validasi ahli materi, maka dengan segera validasi ke ahli media. Ahli media memberikan saran dan masukan untuk memperbaiki kualitas Perangkat Pembelajaran yang sedang dikembangkan. Proses validasi media peneliti melalui dua tahap yaitu tahap I dan tahap II. Data validasi ahli media tahap I dijadikan dasar untuk merevisi Perangkat Pembelajaran kedua. Setelah selesai revisi yang kedua divalidasi lagi hingga Perangkat Pembelajaran siap digunakan untuk uji coba. Uji coba dilakukan dengan dua tahap, yaitu tahap uji coba kelompok kecil dan uji coba kelompok besar. Setelah revisi akhir maka didapat Perangkat Pembelajaran akhir yang siap digunakan Mahasiswa sebagai sumber belajar untuk meningkatkan Kreativitas Mahasiswa. Kualitas Perangkat Pembelajaran Penanganan dan perawatan cedera olahraga ini termasuk dalam kriteria "Layak". Pernyataan tersebut dapat dibuktikan dari hasil analisis penilaian "Layak" dari kedua ahli baik itu ahli materi dan ahli media, serta dalam penilaian uji coba kelompok kecil dan uji coba kelompok besar. Mahasiswa merasa senang dengan adanya Perangkat Pembelajaran ini karena mereka tertarik untuk belajar dan memperoleh pengetahuan baru.

Ada beberapa hal yang menurut pendapat Mahasiswa menjadi kelebihan Perangkat Pembelajaran ini. Diantaranya yaitu Pembelajaranya Kontestual dan Komposisi Bahan Untuk Penangana Cederanya Mudah di Dapatkan sekitar, isi buku mudah dipahami, dan dapat menggali informasi baru yang bermanfaat untuk Mahasiswa. Selain dengan adanya kelebihankelebihan dari Perangkat Pembelajaran ini, adapun kelemahan dalam Perangkat Pembelajaran ini, diantaranya hanya beberapa gambar hasil foto sendiri, sedangkan lebih banyak gambar hasil dari browsing internet. Adanya beberapa kelemahan tersebut, perhatian dan upaya pengembangan selanjutnya dapat dilakukan untuk memperoleh hasil Perangkat Pembelajaran yang lebih baik. Kenyataan ini akan semakin membuka peluang untuk senantiasa diadakannya pembenahan selanjutnya. Setelah melalui uji coba Perangkat Pembelajaran (kelompok kecil dan kelompok besar) maka dapat dijabarkan kelebihan dan kekurangan Perangkat Pembelajaran Penanganan dan perawatan cedera.

1. Kelebihan Perangkat Pembelajaran:

a. Perangkat Pembelajaran dapat digunakan sebagai sumber belajar Mahasiswa dengan tampilan yang menarik sehingga materi mudah dipahami.

b. Dapat menggali informasi untuk Mahasiswa dan Mahasiswa Lebih Kreatif dalam Meracik Ramuan.

c. Dapat menuntun mahasiswa dalam memecahkan masalah khususnya dalam hal cedera.

d. Pengetahuan Mahasiswa mengenai Penanganan dan perawatan cedera bertambah.

2. Kekurangan Perangkat Pembelajaran:

a. Kekurangan dalam Perangkat Pembelajaran ini adalah gambar yang bukan hasil foto sendiri melainkan hasil dari browsing internet. 
b. Pengadaan Perangkat Pembelajaran masih relatif mahal dalam hal Perangkat Pembelajaran media.

Pengenalan Penanganan dan perawatan cedera untuk Mahasiswa sebelumnya cenderung belum ada. Perangkat Pembelajaran Penanganan dan perawatan cedera ini di desain dengan konsep menarik dan mudah dipahami sehingga diharapkan mahasiswa merasa tertarik dalam mempelajari dan dapat menambah pengetahuan mahasiswa. Dari hasil analisis Perangkat Pembelajaran Penanganan dan perawatan cedera selama uji coba Perangkat Pembelajaran dapat dijabarkan sebagai berikut:

1. Mahasiswa:

a. Mahasiswa tertarik dalam mempelajari materi pengenalan Penanganan dan perawatan cedera dengan mengamati gambar serta penjelasan yang ada dalam Perangkat Pembelajaran tersebut. Mahasiswa menjadi lebih tahu mengenai Penanganan yang harus dilakukan pada saat terjadinya cedera.

b. Pengetahuan Mahasiswa menjadi bertambah mengenai Penanganan dan perawatan cedera. Sehingga Mahasiswa dapat mengimplementasikan apabila terjadi cedera.

2. Dosen:

a. Dapat digunakan oleh Dosen sebagai sumber belajar Mahasiswa.

b. Dosen lebih mudah dalam memperkenalkan Penanganan dan perawatan cedera kepada Mahasiswa dengan menggunakan Perangkat Pembelajaran tersebut.

Pemanfaatan Perangkat Pembelajaran Penanganan dan perawatan cedera masih terdapat beberapa hambatan. Gambar yang terkesan mengerikan membuat beberapa Mahasiswa merasa mual, takut untuk membaca. Kedepannya Perangkat Pembelajaran Penanganan dan perawatan cedera diharapkan dapat lebih disempurnakan.

\section{SIMPULAN DAN SARAN}

\section{A. Simpulan}

Pengembangan Perangkat Penanganan dan perawatan cedera olahraga yang telah dikembangkan dalam penelitian ini layak digunakan sebagai media Pembelajaran untuk Meningkatkan Kemampuan Berpikir Kreatif Mahasiswa antentang Penanganan dan perawatan cedera dengan prosedur (1) Identifikasi Potensi dan Masalah, (2) Pengumpulan Bahan, (3) Desain Perangkat Perangkat Pembelajaran, (4) Pembuatan Produk, (5) Validasi Produk, (6) Revisi Produk, (7) Produk Akhir, (8) Uji Coba Produk. Selain itu ditinjau dari hasil penilaian Buku Ajar, LKM, RPS, Instrumen tes Berpikir Kreatif Mahasiswa:

1. Secara keseluruhan, Perangkat Pembelajaran Penanganan dan perawatan cedera dengan pokok bahasan materi (luka terbuka dan luka tertutup) ini dikategorikan layak digunakan dalam pengenalan Penanganan dan perawatan cedera olahraga untuk mahasiswa dengan tingkat kelayakan sebesar 83\%. Secara keseluruhan dari ahli media dikategorikan layak digunakan dengan tingkat kelayakan sebesar $80 \%$.

2. Bedasarkan uji coba kelompok besar, kelayakan dari buku saku Penanganan dan perawatan cedera olahraga meliputi:

a) Segi materi sebesar $88 \%$.

b) Segi keterbacaan bahasa sebesar $90 \%$.

c) Segi penyajian Penyajian Perangkat Pembelajaran (Buku Ajar, LKM, RPS, Instrumen tes Berpikir Kreatif Mahasiswa) 92\%.

d) Segi Komposisi Perangkat Pembelajaran/Ramuan "Loi Ncara Ro Mpoka 90\%.

Secara keseluruhan Perangkat Pembelajaran Penanganan dan perawatan cedera olahraga ini layak digunakan dalam penerapan Penanganan dan perawatan cedera olahraga untuk Mahasiswa 
setelah melalui 2 tahap uji coba. Penelitian pengembangan ini sudah tercapai untuk digunakan oleh Dosen dalam memperkenalkan Penanganan dan perawatan cedera olahraga kepada mahasiswa.

\section{B. Saran}

Berdasarkan hasil penelitian yang telah dilakukan, salah satu saran yang dapat dikemukakan oleh peneliti yaitu diharapkan Mahasiswa dapat menggunakan Media dan perangkat pembelajaran untuk mempermudah memahami materi tentang Penangan dan Perawatan Cedera (PPC) Lebih Kontestual dan lebih Kreatif untuk memperdayakan tumbuhan dan tanaman Tradisional.

\section{DAFTAR RUJUKAN}

Afrianti, I., Wahyuni, N., \& Rusdin, R. (2021). Pembelajaran Berbasis Lingkungan untuk Menambah Penguasaan Leksikon Bahasa Inggris Mahasiswa. Ainara Journal (Jurnal Penelitian Dan PKM Bidang Ilmu Pendidikan), 2(4), 150-157. https://doi.org/10.54371/ainj.v2i4.97

Ali Satia Graha dan Bambang Priyonoadi. (2009). Terapi Masase Frirage. Pelaksanaan cedera pada anggota tubuh bagian atas. Yogyakarta: FIK UNY.

Andun Sudijandoko. (2000). Perawatan dan Pencegahan Cedera. Jakarta: Depdiknas

Arikunto, S. (2009). Prosedur Penelitian Suatu Pendekatan Praktik. Edisi Revisi 6. Jakarta : Rineka Cipta.

Borg, W.R. \& Gall, M.D. Gall. (1983). Educational Research: An Introduction, Fifth Edition. New York: Longman.

C.K. Giam and K.C. Teh. (1992). Ilmu Kedokteran Olahraga (Hartono Satmoko, Terjemah). Jakarta: Penerbit: FIK UNY.

Cerika R. dan Yustinus Sukarmin. (2006). Usaha-usaha Pencegahan Cedera Olahraga pada Pemain Bolabasket. Jurnal Ilmiah Kesehatan Olahraga MEDIKORA.Yogyakarta: FIK UNY.

Devi Tirtawirya. (2008). Cedera pada Olahraga Taekwondo. Majalah Ilmiah Olahraga. Yogyakarta:FIK UNY.

Fauzi, I. B., \& Priyonoadi, B. (2019). Klasifikasi dan Pemahaman Penanganan.

Ginanjar, G., \& Budiana, D. (2018). Penerapan Model Pembelajaran Hellison Untuk Meningkatkan Nilai Tanggung Jawab Siswa Dalam Penggunaan Alat

Haryadi Sarjono \& Winda Julianita.(2010). SPSS vs LISREL, Sebuah Pengantar untuk Riset.Jakarta: Salemba Empat.

Hisrich, R.D; Peters. M.P \& Shepherd, D.A. (2008). Kewirausahaan Edisi 7. Terjemahan Chriswan, S \& Diana A. Penerbit Salemba Empat, Jakarta.

\section{http://www.ichrc.org/932-prinsip-perawatan-luka. Diakses pada tanggal 03 Januari 2014}

Kartono Mohammad. (2005). Penanganan Pertama. Jakarta: PT Gramedia Pustaka Utama.

Margaretha, Y; Harianti, A; Lisan, H. (2012). Analisis Perbedaan Tingkat Kreativitas Mahasiswa

Sebelum dan Sesudah diberi Pengajaran Kewirausahaan. Fakultas Ekonomi Universitas Kristen aranatha, Bandung. 
Morgan II Lyle. (1995). Mengobati Cedera Secara Alamiah. Jakarta: Penerbit: Bumi Aksara.

Pembelajaran Penjas. TEGAR: Journal of Teaching Physical Education in Elementary School, 1, 41.

Sugiyono. (2013). Metode Penelitian Kuantitatif, Kualitatif, dan Kombinasi. Bandung: PT Alfabeta.

Sumartiningsih, S. (2012). Cedera Keseleo pada Pergelangan Kaki (Ankle Sprains). Jounal.

Suryana. (2011). Kewirausahaan Pedoman Praktis: Kiat dan Proses Menuju Sukses. Penerbit Salemba Empat, Jakarta.

Taufik, \& Erwin, Husnul Khatimah (2020) Pengembangan Perangkat Pembelajaran Model CIRC pada Mata Kuliah Apresiasi Sastra "Mantra Mbojo" untuk Melatih Kemampuan Berpikir Kreatif Mahasiswa. Jounal JIIP. 2020

TBMM. (2002). Buku Panduan Pelatihan Basic Life Support. Yogyakarta: Panacea Yogyakarta. 